\title{
References
}

Aalto, P. and Forsberg, T. 2016. 'The structuration of Russia's geo-economy under economic sanctions'. Asia Europe Journal, 14(2): 221-37.

Abdelal, R., McDermott, R., Herrera, Y.M. and Johnston, A.I. 2006. 'Identity as a variable'. Perspectives on Politics, 4(4): 695-711.

Acharya, A. 2007. 'The emerging regional architecture of world politics'. World Politics, 59(4): 629-52.

Acharya, A. 2014. 'Global international relations (IR) and regional worlds'. International Studies Quarterly, 58(4): 647-59.

Adler, E. 1997. 'Seizing the middle ground: constructivism in world politics'. European Journal of International Relations, 3(3): 319-63.

Adler, E. 2012. 'Constructivism in international relations: sources, contributions, and debates'. In W. Carlsnaes, T. Risse and B.A. Simmons (eds), Handbook of International Relations. London: Sage, pp. $112-44$.

Al Jazeera. 2014. 'Ukraine president meets opposition leaders as protests turn deadly', Al Jazeera, 22 January. Available: http://america.aljazeera. com/articles/2014/1/22/ukraine-presidentmeetswithoppositionleadersas proteststurndeadly.html (accessed 26 March 2015).

Al Jazeera. 2015. 'Russia extends tit-for-tat sanctions against West', Al Jazeera, 24 June. Available: http:/www.aljazeera.com/news/2015/06/ russia-extends-tit-tat-sanctions-west-150624131713532.html (accessed 12 November 2015).

Alexander's Gas and Oil Connections. 2010. 'Ukraine joins energy community', 27 September. Available: http:/www.gasandoil.com/news/2010/12/ nte105074 (accessed 15 september 2014).

Ambrosio, T. 2006. 'The political success of Russia-Belarus relations: insulating Minsk from a color revolution'. Demokratizatsiya: The Journal of Post-Soviet Democratization, 14(3): 407-34.

Ambrosio, T. 2007. 'Insulating Russia from a colour revolution: how the Kremlin resists regional democratic trends'. Democratization, 14(2): 232-52.

Ambrosio, T. 2010. 'Constructing a framework of authoritarian diffusion: concepts, dynamics, and future research'. International Studies Perspectives, 11(4): 375-92. 
Andoura, S. and Vinois, J. 2015. 'From the European energy community to theenergy union'. Jacques Delors Institute, January. Available: http://www. institutdelors.eu/media/energyunion-andouravinois-jdi-jan15.pdf?pdf= ok (accessed 15 June 2015).

Andoura, S., Hancher, L. and Van der Woude, M. 2010. Towards a European Energy Community: A Policy Proposal. Paris: Notre Europe.

Andreatta, F. 2011. 'The European Union's international relations: a theoretical view'. In C. Hill and M. Smith (eds), International Relations and the European Union. The New European Union Series. Oxford: Oxford University Press, pp. 21-43.

Arbatov, A. 1993. 'Russia's foreign policy alternatives'. International Security, 18(2): 5-43.

Aron,L.2013.'ThePutindoctrine'.Foreign Affairs, 8 March.Available:https:// www.foreignaffairs.com/articles/russian-federation/2013-03-08/putin-do ctrine (accessed 15 March 2015).

Åslund, A. 2013. 'Sergey Glazyev and the revival of Soviet economics'. Post-Soviet Affairs, 29(5): 375-86.

Åslund, A. 2014. 'Oligarchs, corruption, and European integration'. Journal of Democracy, 25(3): 64-73.

Averre, D. 2007. "Sovereign democracy" and Russia's relations with the European Union'. Demokratizatsiya, 15(2): 173-90.

Averre, D. 2010. 'The EU, Russia and the shared neighbourhood: security, governance and energy'. European Security, 19(4): 531-4.

Baev, P.K. and Øverland, I. 2010. 'The South Stream versus Nabucco pipeline race: geopolitical and economic (IR) rationales and political stakes in megaprojects'. International Affairs, 86(5): 1075-90.

Baker, L. 2014. 'EU offers Ukraine $\$ 15$ billion, but help hinges on IMF deal'. Reuters, 5 March. Available: http://www.reuters.com/article/useu-ukraine-support-idUSBREA240V020140305 (accessed 15 March 2015).

Baldwin, D.A. 2012. 'Power and international relations'. In W. Carlsnaes, T. Risse and B.A. Simmons (eds), Handbook of International Relations. London: Sage, p. 273.

Baldwin, M. 2006. 'EU trade politics - heaven or hell?' Journal of European Public Policy, 13(6): 926-42.

Balfour, R. 2013. Human Rights and Democracy in EU Foreign Policy: The Cases of Ukraine and Egypt. Abingdon, UK: Routledge.

Balmforth, R. 2013a. 'UPDATE 2 - Ukraine hints at compromise in gas talks with Russia'. Reuters, 1 March. Available: http://www.reuters. com/article/2013/03/01/ukraine-russia-talks-idUSL6N0BT7KE20130301 (accessed 23 February 2015).

Balmforth, R. 2013b. 'Ukraine leader urges pro-Europe drive despite 
Kremlin pressure'. Reuters, 3 September. Available: http://www.reuters. com/article/2013/09/03/us-ukraine-russia-yanukovich-idUSBRE9 820HG20130903 (accessed 23 February 2015).

Baranovsky, V. 2000. 'Russia: a part of Europe or apart from Europe?' International Affairs, 76(3): 443-58.

Bassin, M. 1991. 'Russia between Europe and Asia: the ideological construction of geographical space'. Slavic Review, 50(1): 1-17.

BBC. 2005. 'Yushchenko seeks EU membership'. BBC News, 25 January. Available: http://news.bbc.co.uk/2/hi/europe/4204149.stm (accessed 15 March 2015).

BBC. 2014. 'Ukraine: Putin signs Crimea annexation'. BBC News, 21 March. Available: http://www.bbc.com/news/world-europe-26686949 (accessed 15 March 2015).

BBC. 2015. "MH17: "Russian-made missile parts" at Ukraine crash site'. BBC News, 11 August. Available: http://www.bbc.com/news/worldeurope-33865420 (accessed 27 January 2016).

Beissinger, M.R. 2009. 'An interrelated wave'. Journal of Democracy, 20(1): 74-7.

Beissinger, M.R. 2015. 'Self-determination as a technology of imperialism: the Soviet and Russian experiences'. Ethnopolitics, 14(5): 479-87.

Belarus, Kazakhstan and the Russian Federation. 2007. The Establishment of a Single Customs Territory and Formation of the Customs Union. Available: https://docs.eaeunion.org/en-us (accessed 5 July 2014).

Bendiek, A. 2012. 'European realism in the EU's common foreign and security policy'. In P.J. Cardwell (ed.), EU External Relations Law and Policy in the Post-Lisbon Era. The Hague: Asser Press, pp. 35-57.

Berryman, J. 2012. 'Geopolitics and Russian foreign policy'. International Politics, 49(4): 530-44.

Bershidsky, L. 2016. 'How Ukraine weaned itself off Russian gas'. Bloomberg, 12 January. Available: http://www.bloombergview.com/ articles/2016-01-12/how-ukraine-weaned-itself-off-russian-gas (accessed 5 March 2016).

Bianco, V., Scarpa, F. and Tagliafico, L.A. 2015. 'Current situation and future perspectives of European natural gas sector'. Frontiers in Energy, 9(1): $1-6$.

Bildt, C., Hague, W., Schwarzenberg, K., Sikorski, R. and G. Westerwelle. 2012. 'Ukraine's Slide'. New York Times, 4 March. Available: http://www. nytimes.com/2012/03/05/opinion/05iht-edbildt05.html (accessed 5 July 2014).

Birnbaum, M. 2015. 'E.U. extends sanctions against Russia amid a growing split over their future'. Washington Post, 21 December. Available: https:// 
www.washingtonpost.com/world/eu-extends-sanctions-against-russiaamid-growing-splits-over-their-future/2015/12/21/16157de6-a381-11e 5-8318-bd8caed8c588_story.html (accessed 5 November 2015).

Blair, D. 2014. 'Ukraine crisis: rebels proclaim birth of sovereign "People's Republic". Telegraph, 12 May. Available: http://www.telegraph. co.uk/news/worldnews/europe/ukraine/10823960/Ukraine-crisis-rebelsproclaim-birth-of-sovereign-Peoples-Republic.html (accessed 5 November 2015).

Blinnikov, M.S. 2011. A Geography of Russia and its Neighbors. New York: Guilford Press.

Bolton, D. 2016. 'Russia names US and Nato as national security threats for the first time'. Inderpendent, 4 January. Available: http://www.inde pendent.co.uk/news/world/americas/russia-names-us-nato-as-nationalsecurity-threats-a6795181.html (accessed 5 March 2016).

Börzel, T.A. 2011. 'When Europe hits beyond its borders: Europeanization and the "near abroad"'. Comparative European Politics, 9(4-5): 394-413.

Börzel, T.A. and Risse, T. 2011. 'From Europeanisation to diffusion: introduction'. West European Politics, 35(1): 1-19.

Bosse, G. and Korosteleva-Polglase, E. 2009. 'Changing Belarus?' Cooperation and Conflict, 44(2): 143-65.

Bouzarovski, S., Petrova, S. and Sarlamanov, R. 2012. 'Energy poverty policies in the EU: a critical perspective'. Energy Policy, 49, 76-82.

Bressand, A. 2011. 'Between Kant and Machiavelli: EU foreign policy priorities in the 2010s'. International Affairs, 87(1): 59-85.

Brooks, S.G. and Wohlforth, W.C. 2010. World Out of Balance: International Relations and the Challenge of American Primacy. Princeton, NJ: Princeton University Press.

Burlyuk, O. 2015. 'Variation in EU external policies as a virtue: EU rule of law promotion in the neighbourhood'. JCMS: Journal of Common Market Studies, 53(3): 509-23.

Bussière, M., Fidrmuc, J. and Schnatz, B. 2008. 'EU enlargement and trade integration: lessons from a gravity model'. Review of Development Economics, 12(3): 562-76.

Buzan, B. and Waever, O. 2003. Regions and Powers: The Structure of International Security. Cambridge: Cambridge University Press.

Carlsnaes, W. 2004. 'Where is the analysis of European foreign policy going?' European Union Politics, 5(4): 495-508.

Casier, T. 2011a. 'The EU's two-track approach to democracy promotion: the case of Ukraine'. Democratization, 18(4): 956-77.

Casier, T. 2011b. 'The rise of energy to the top of the EU-Russia agenda: from interdependence to dependence?' Geopolitics, 16(3): 536-52.

Casier, T. 2012. 'Are the policies of Russia and the EU in their shared 
neighbourhood doomed to clash?' In R.E. Kanet and M.R. Freire (eds), Competing for Influence: The EU and Russia in Post-Soviet Eurasia. Dordrecht: Republic of Letters, pp. 31-53.

Cebeci, M. 2012. 'European foreign policy research reconsidered: constructing an "ideal power Europe" through theory? Millennium Journal of International Studies, 40(3): 563-83.

Cha, V.D. 2000. 'Abandonment, entrapment, and neoclassical realism in Asia: the United States, Japan, and Korea'. International Studies Quarterly, 44(2): 261-91.

Chaban, N., Elgström, O., Kelly, S. and Suet Yi, L. 2013. 'Images of the EU beyond its borders: issue-specific and regional perceptions of European Union Power and leadership'. JCMS: Journal of Common Market Studies, 51(3): 433-51.

Chaban, N. and Holland, M. 2008. The European Union and the Asia-Pacific: Media, Public, and Elite Perceptions of the EU. New York: Routledge.

Chafetz, G. 1996. 'The struggle for a national identity in post-Soviet Russia'. Political Science Quarterly, 111(4): 661-88.

Checkel, J.T. 1993. 'Ideas, institutions, and the Gorbachev foreign policy revolution'. World Politics, 45(2): 271-300.

Checkel, J.T. and Moravcsik, A. 2001. 'A constructivist research program in EU studies?' European Union Politics, 2(2): 219-49.

Christensen, T.J. 1996. Useful Adversaries: Grand Strategy, Domestic Mobilization, and Sino-American Conflict, 1947-1958. Princeton, NJ: Princeton University Press.

Christiansen, T., Jørgensen, K.E. and Wiener, A. 2001. The Social Construction of Europe. London: Sage.

Christou, G. 2010. 'European Union security logics to the east: the European neighbourhood policy and the Eastern partnership'. European Security, 19(3): 413-30.

CIA. The World Factbook. Available: https://www.cia.gov/library/publica tions/the-world-factbook/ (accessed 1 March 2016).

Cini, M. 2007. 'Intergovernmentalism'. In M. Cini (ed.), European Union Politics. Oxford: Oxford University Press, pp. 99-116.

Cooper, A.F. and Flemes, D. 2013. 'Foreign policy strategies of emerging powers in a multipolar world: an introductory review'. Third World Quarterly, 34(6): 943-62.

Copsey, N. and Pomorska, K. 2014. 'The influence of newer member states in the European Union: the case of Poland and the Eastern partnership'. Europe-Asia Studies, 66(3): 1-23.

Council of the EU. 2004. Council Directive 2004/67/EC of 26 April 2004 Concerning Measures to Safeguard Security of Natural Gas Supply, 29/04/2004 P. 0092-0096, Brussels. 
Council of the EU. 2009. Joint Declaration of the Prague Eastern Partnership Summit, 8435/09 (Presse 78), Prague.

Council of the EU. 2012. Council Conclusion on Ukraine, 3209th Foreign Affairs Council meeting, Brussels.

Council of the EU. 2015. 'Reinforced restrictive measures against Russia'. 179/14 (Presse 460), Brussels.

Cronin, B. 2001. 'The paradox of hegemony: America's ambiguous relationship with the United Nations'. European Journal of International Relations, 7(1): 103-30.

Cross, S. 2015. 'NATO-Russia security challenges in the aftermath of Ukraine conflict: managing Black Sea security and beyond'. Southeast European and Black Sea Studies, 15(2): 151-77.

Dabrowski, M. and Taran, S. 2012. 'Is free trade with the EU good for Ukraine?' CASENetworkE-briefs,6. Available:http://www.case-research. eu/sites/default/files/publications/2012-06_Dabrowski_Taran.pdf (accessed 5 November 2015).

Dannreuther, R. 2004. 'Introduction'. In R. Dannreuther (ed.), EU Foreign and Security Policy: Towards a Neighbourhood Strategy. New York: Routledge, pp 1-14.

David, M., Gower, J. and Haukkala, H. 2011. 'Introduction: the European Union and Russia'. Journal of Contemporary European Studies, 19(2): 183-8.

de Jong, S. 2016. 'Confuse, divide and rule - how Russia drives Europe apart'. IES Policy Brief, 2016/2, March.

Dettke, D. 2011. 'Europe and Russia: from neighborhood without a shared vision to a modernization partnership'. European Security, 20(1): $127-42$.

Deutsch, K.W. 1957. Political Community and the North Atlantic Area: International Organization in the Light of Historical Experience. Princeton, NJ: Princeton University Press.

Deutsch, K.W. and Singer, J.D. 1964. 'Multipolar power systems and international stability'. World Politics, 16(3): 390-406.

Deutsche Welle. 2015. 'EU, Russia, Ukraine trade talks fail'. DW Trade, 21 December. Available: http://www.dw.com/en/eu-russia-ukraine-tradetalks-fail/a-18933292 (accessed 5 March 2016).

Diesen, G. 2015. EU and NATO Relations with Russia: After the Collapse of the Soviet Union, Farnham, UK: Ashgate.

Diez, T. 2013. 'Normative power as hegemony'. Cooperation and Conflict, 48(2): 194-210.

Dimitrova, A. and Dragneva, R. 2009. 'Constraining external governance: interdependence with Russia and the CIS as limits to the EU's rule transfer in the Ukraine'. Journal of European Public Policy, 16(6): 853-72. 
Diuk, N. 2014. 'Euromaidan: Ukraine's self-organizing revolution'. World Affairs, 176(6): 9-16.

Donaldson, R.H. and Nogee, J.L. 2014. The Foreign Policy of Russia: Changing Systems, Enduring Interests. New York: M.E. Sharpe.

Dragneva, R. and Wolczuk, K. 2012. 'Russia, the Eurasian Customs Union and the EU: cooperation, stagnation or rivalry? Chatham House Briefing Paper.

Economist, The. 2013. 'Ukraine and Russia: trading insults'. The Economist, 24 August. Available: http://www.economist.com/news/europe/21583998trade-war-sputters-tussle-over-ukraines-future-intensifies-trading-insults (accessed 12 June 2015).

Economist, The. 2014. 'The February revolution'. The Economist, 1 May. Available: http://www.economist.com/news/briefing/21597974can-ukraine-find-any-leaders-who-will-live-up-aspirations-its-batteredvictorious (accessed 12 June 2015).

Egeberg, M. 1999. 'Transcending intergovernmentalism? Identity and role perceptions of national officials in EU decision-making'. Journal of European Public Policy, 6(3): 456-74.

Elgström, O. 2007. 'Outsiders' perceptions of the European Union in international trade negotiations'. JCMS: Journal of Common Market Studies, 45(4): 949-67.

Emerson, M., Balfour, R., Corthaut, T., Wouters, J., Kaczynski, P.M. and Renard, T. 2011. Upgrading the EU's Role as Global Actor: Institutions, Law and the Restructuring of European Diplomacy. Brussels: Centre for European Policy Studies.

Emmott, R. 2016. 'European leaders are going to great lengths to revive economic ties with Iran'. Business Insider, 9 March. Available: http://www. businessinsider.com/r-europe-steps-back-in-time-to-revive-iran-ties-20163? IR = T (accessed 16 March 2016).

Energy Community. 2005. Treaty Establishing the Energy Community, Athens.

Energy Community. 2009. Protocol Concerning the Accession of Ukraine to the Treaty Establishing the Energy Community. Available: https:// www.energy-community.org/pls/portal/docs/728177.PDF (accessed 5 November 2015).

Eskelinen, H., Liikanen, I. and Scott, J.W. 2012. The EU-Russia Borderland: New Contexts for Regional Cooperation. Abingdon, UK: Routledge.

Euractiv. 2010. 'Ukraine's Yanukovich pledges to work for EU integration'. Euractiv, 2 March. Available: http://www.euractiv.com/ east-mediterranean/ukraine-s-yanukovich-pledges-work-eu-integrationnews-299768 (accessed 5 November 2015).

Euractiv. 2013. 'Ukraine rejects pre-conditions for EU deal'. Euractiv, 
21 February. Available: http://www.euractiv.com/europes-east/ukrainerejects-pre-conditions-e-news-517934 (accessed 5 November 2015).

Euractiv.2014. 'EUtriestolimitdamagefromRussianfoodembargo'.Euractiv, 12 August. Available: http://www.euractiv.com/section/europe-s-east/ news/eu-tries-to-limit-damage-from-russian-food-embargo/ (accessed 5 November 2015).

Euractiv. 2015. 'EU, Russia, Ukraine agree winter gas supply deal'. Euractiv, 28 September. Available: http://www.euractiv.com/section/europe-seast/news/eu-russia-ukraine-agree-winter-gas-supply-deal/ (accessed 5 November 2015).

Eurasian Economic Commission. 2013. Eurasian Economic Integration: Facts and Figures. Available: http://www.eurasiancommission.org/ru/ Documents/broshura26Body_ENGL_final.pdf (accessed 15 December 2015).

Eurasian Economic Commission. 2014. The Treaty on the Eurasian Economic Union is Effective. Available: http://www.eurasiancommis sion.org/en/nae/news/Pages/01-01-2015-1.aspx (accessed 15 December 2015).

Eurasian Economic Union. 2014. Treaty on the Eurasian Economic Union. Available: https://docs.eaeunion.org/sites/storage0/Lists/Documents/a0 89f4c6-02da-4461-b033-3f5d122e0020/e57db9f2-9589-4b26-be1e-b1a43 862c6ed_635375701449140007.pdf (accessed 15 December 2015).

Eurogas. 1995. Statistics 1995. Available: http://www.eurogas.org/uploads/ media/Eurogas_Statistics_1995.pdf (accessed 12 October 2014).

Eurogas. 2011. Statistical Report 2011. Available: http://www.eurogas. org/uploads/media/Statistics_2011_09.12.11.pdf (accessed 12 October 2014). http://www.eurogas.org/uploads/media/Eurogas_Statistical_Re port_2014.pdf.

Eurogas. 2014. Statistical Report 2014. Available: http://www.eurogas. org/uploads/media/Eurogas_Statistical_Report_2014.pdf (accessed 12 October 2014).

Eurogas. 2015. Statistical Report 2015. Available: http://www.eurogas.org/ uploads/2016/flipbook/statistical-report-2015/index.html (accessed 12 October 2014).

European Communities and Ukraine. 1994. Partnership and Cooperation Agreement, CE/UKR/en, Brussels.

European Commission. 2003. Wider Europe - Neighbourhood: A New Framework for Relations with our Eastern and Southern Neighbours, COM/2003/0104, Brussels.

European Commission. 2005. EU/Ukraine Action Plan, Brussels. Available: http://www.enpi-info.eu/library/sites/default/files/attachments/ukraine_ enp_ap_final_en_0.pdf (accessed 18 February 2015). 
European Commission. 2007a. An Energy Policy for Europe, COM(2007) 1, Brussels.

European Commission. 2010. Energy 2020. A Strategy for Competitive, Sustainable and Secure Energy, COM(2010) 639, Brussels.

European Commission. 2011. Implementation of the European Neighbourhood Policy in 2010 Country Report: Ukraine, SEC(2011) 646, Brussels.

European Commission. 2012. Implementation of the European Neighbourhood Policy in Ukraine Progress in 2011 and Recommendations for Action, SWD(2012) 124, Brussels.

European Commission. 2013a. EU-Ukraine Deep and Comprehensive Free Trade Area. Available: http://trade.ec.europa.eu/doclib/docs/2013/april/ tradoc_150981.pdf.

European Commission. 2013b. Implementation of the European Neighbourhood Policy in Ukraine Progress in 2012 and Recommendations for Action, SWD(2013) 84, Brussels.

European Commission. 2015a. European Union, Trade in Goods with Russia, DG Trade, Brussels. Available: http://trade.ec.europa.eu/doclib/ docs/2006/september/tradoc_113440.pdf.

European Commission. 2015b. European Union, Trade in Goods with Ukraine, DG Trade, Brussels. Available: http://trade.ec.europa.eu/ doclib/docs/2006/september/tradoc_113459.pdf.

European Commission. 2015c. 'The trade part of the EU-Ukraine Association Agreement becomes operational on 1 January 2016'. Press release, 31 December. Available: http://europa.eu/rapid/press-release_ IP-15-6398_en.htm (accessed 12 January 2016).

European Commission. 2015d. A Framework Strategy for a Resilient Energy Union with a Forward-looking Climate Change Policy, COM/2015/080 final.

European Commission and Ukraine. 2013. EU-Ukraine Association Agenda. Available: http://eeas.europa.eu/ukraine/docs/eu_ukr_ass_ agenda_24jun2013.pdf (accessed 12 October 2014).

European Council. 1991. Presidency Conclusions, Bulletin 02.01.91, Luxembourg.

European Council. 2014. Conclusions, EUCO 7/1/14, Brussels.

European Parliament and Council of the EU. 2003. Directive 2003/55/ EC of the European Parliament and of the Council of 26 June 2003 Concerning Common Rules for the Internal Market in Natural Gas and Repealing Directive 98/30/EC, 15/07/2003 P. 0057-0078, Brussels.

European Parliament and Council of the EU. 2005. Regulation (EC) No 1775/2005 of the European Parliament and of the Council of 28 September 2005 on Conditions for Access to the Natural Gas Transmission Networks, OJ L 289, 3.11.2005, Brussels. 
European Parliament and Council of the EU. 2009. Directive 2009/73/ EC of the European Parliament and of the Council of 13 July 2009 Concerning Common Rules for the Internal Market in Natural Gas and Repealing Directive 2003/55/EC, OJ L 211, 14.8.2009, Brussels.

European Union. 2012. Consolidated Version of the Treaty on the Functioning of the European Union, OJ C 326, 26.10.2012, Lisbon. Available: http://eurlex.europa.eu/legal-content/EN/TXT/?uri=celex:12012E/TXT (accessed 12 October 2014).

European Union and Ukraine. 2005. Memorandum of Understanding on Co-operation in the Field of Energy Between the European Union and Ukraine, Kiev. Available: https://ec.europa.eu/energy/sites/ener/files/ documents/2010_ukraine_mou.pdf (accessed 12 October 2014).

Feduschak, N.A.2010. 'CriticspounceondealtoletRussianBlackSeafleetstay in Crimea until 2042'. Kyiv Post, 23 April. Available: http://www.kyivpost. com/content/ukraine/critics-pounce-on-deal-to-let-russian-black-sea-fl64790.html (accessed 12 October 2014).

Fiaz, N. 2014. 'Constructivism meets critical realism: explaining Pakistan's state practice in the aftermath of 9/11'. European Journal of International Relations, 20(2): 491-515.

Foreign Policy Bulletin. 1991. 'Inaugural Speech by President Boris Yeltsin of the Republic of Russia'. Foreign Policy Bulletin, 2(1).

Forsberg, T. 2013. 'The power of the European Union'. Politique européenne, 1: 22-42.

Forsberg, T. and Haukkala, H. 2015. 'The end of an era for institutionalism in European Security?' Journal of Contemporary European Studies, 23(1): 1-5.

Forsberg, T. and Seppo, A. 2009. 'Power without Influence? The EU and trade disputes with Russia'. Europe-Asia Studies, 61(10): 1805-23.

Francés, G.E. 2011. 'Market or geopolitics? The Europeanization of EU's energy corridors'. International Journal of Energy Sector Management, 5(1): 39-59.

Frizell, S. 2014. 'Russia vows to defend itself if "interests" attacked in Ukraine'. Time, 23 April. Available: http://time.com/74129/russialavrov-ukraine-kremlin/ (accessed 20 December 2015).

Fukuyama, F. 1989. 'The end of history?' The National Interest, 16(Summer): 3-18.

Füle, S. 2013. 'Statement on the pressure exercised by Russia on countries of the Eastern Partnership'. European Commission, press release, 11 September. Available: http://europa.eu/rapid/press-release_SPEECH13-687_en.htm (accessed 20 December 2015).

Galeotti, M. 2014. 'The missile that will end the war'. Foreign Policy, 
18 July. Available: http://foreignpolicy.com/2014/07/18/the-missile-thatwill-end-the-war/ (accessed 20 December 2015).

Gardner, H. 2016. 'The Russian annexation of Crimea: regional and global ramifications'. European Politics and Society, Online first. Available: http://www.tandfonline.com/doi/abs/10.1080/23745118.2016. 1154190 (accessed 20 March 2016).

Gawrich, A., Melnykovska, I. and Schweickert, R. 2010. 'Neighbourhood Europeanization through ENP: the case of Ukraine'. JCMS: Journal of Common Market Studies, 48(5): 1209-35.

Gazprom. 2013. OAO Gazprom Annual Report 2013. Available: http:// www.gazprom.com/f/posts/60/660385/gazprom-annual-report-2013-en. pdf (accessed 20 December 2015).

Gazprom. 2014. Gazprom in Figures 2009-2013 Factbook. Available: http:// www.gazprom.com/f/posts/29/761233/gazprom-in-figures-2009-2013-en. pdf (accessed 20 December 2015).

Gazprom. 2015a. 'Gazprom, BASF, E.ON, ENGIE, OMV and Shell sign shareholders agreement on Nord Stream 2 project'. Press release, 4 September. Available: http://www.gazprom.com/press/news/2015/sep tember/article245837/ (accessed 20 December 2015).

Gazprom. 2015b. Gazprom in Figures 2010-2014. Available: http://www. gazprom.com/f/posts/29/761233/gazprom-in-figures-2010-2014-en.pdf (accessed 20 December 2015).

Gill, G. 2014. 'The stabilization of authoritarian rule in Russia?'. Journal of Elections, Public Opinion \& Parties, 25(1): 62-77.

Gilpin, R. 1983. War and Change in World Politics, Cambridge: Cambridge University Press.

Giusti, S. 2015. 'The EU's policy towards Russia: national interests and path dependency'. In International Relations Theory and European Security: We Thought We Knew. Abingdon, UK: Routledge, pp. 177-96.

Glaser, C.L. 2010. Rational Theory of International Politics: The Logic of Competition and Cooperation. Princeton, NJ: Princeton University Press.

Gleb, B.A. 2007. Russian Natural Gas: Regional Dependence, CRS report for Congress. Available: http://www.au.af.mil/au/awc/awcgate/crs/ rs22562.pdf (accessed 12 October 2014).

Glenn, J. 2009. 'Realism versus strategic culture: competition and collaboration?' International Studies Review, 11(3): 523-51.

Global Firepower. Countries Ranked by Military Strength. Available: http://www.globalfirepower.com/countries-listing.asp (accessed 1 March 2016).

Glosny, M.A. 2009. 'China and the BRICs: a real (but limited) partnership in a unipolar world'. Polity, 42(1): 100-29.

Godzimirski, J.M. 2014. 'Russia’s external energy strategy: opportunities and 
challenges in the next twenty years'. In S. Oxenstierna and V.-P. Tynkkynen (eds), Russian Energy and Security up to 2030. London: Routledge, pp. 213-31.

Goldthau, A. 2008. 'Resurgent Russia? Rethinking Energy Inc.' Policy Review, 147: 56-63.

Goldthau, A. and Boersma, T. 2014. 'The 2014 Ukraine-Russia crisis: implications for energy markets and scholarship'. Energy Research \& Social Science, 3: 13-15.

Gorenburg, D. 2011. 'Ukraine after Yushchenko'. Russian Politics and Law, 49(5): 3-7.

Gorshenin Institute. 2013. '2013 to be turning point for EU-Ukraine relations - expert forecast'. Gorshenin Institute, 12 February. Available: http://gorshenin.eu/news/156_2013_to_be_turning_point_for.html (accessed 12 October 2014).

Graham-Harrison, E., Luhn, A., Walker, S., Sedghi, A. and Rice-Oxley, M. 2015. 'China and Russia: the world's new superpower axis?' Guardian, 7 July. Available: http://www.theguardian.com/world/2015/jul/07/chinarussia-superpower-axis/ (accessed 1 February 2016).

Greene, J. 2012. Russian Responses to NATO and EU-enlargement and Outreach. London: Chatham House.

Gregory, P.R. 2014. 'Poroshenko elected Ukraine president; Putin dodges promiseto "respect'results"'. Forbes, 25 May. Available:http://www.forbes. com/sites/paulroderickgregory/2014/05/25/chocolate-king-elected-presi dent-of-ukraine-as-putin-dodges-his-promise-to-respect-the-election/\# 54e40d485f8c (accessed 1 February 2016).

Grevi, G. 2009. 'The interpolar world: a new scenario'. Occassional Paper No. 79, EU-ISS, Paris.

Grossman, M. 2005. 'Role theory and foreign policy change: the transformation of Russian foreign policy in the 1990s'. International Politics, 42(3): 334-51.

Guardian. 2015. 'The Guardian view on Debaltseve and the Ukraine ceasefire'. Guardian, 18 February. Available: http://www.theguardian.com/ commentisfree/2015/feb/18/guardian-view-ukraine-debaltseve-ceasefire (accessed 1 February 2016).

Gvosdev, N.K. 2014. 'The bear awakens: Russia's military is back'. The National Interest, 12 November. Available: http://nationalinterest.org/ commentary/russias-military-back-9181 (accessed 1 February 2016).

Hadfield, A. 2008. 'EU-Russia energy relations: aggregation and aggravation'. Journal of Contemporary European Studies, 16(2): 231-48.

Hadfield-Amkhan, A. 2010. British Foreign Policy, National Identity, and Neoclassical Realism. Lanham, MD: Rowman \& Littlefield.

Hagemann, C. 2013. 'External governance on the terms of the partner? 
The EU, Russia and the Republic of Moldova in the European Neighbourhood Policy'. Journal of European Integration, 35(7): 767-83. Hale, H.E. 2006. 'Democracy or autocracy on the march? The colored revolutions as normal dynamics of patronal presidentialism'. Communist and Post-Communist Studies, 39(3): 305-29.

Hale, H.E., Kravets, N. and Onuch, O. 2015. 'Can federalism unite Ukraine in a peace deal?'. PONARS Eurasia, August. Available: http:// www.ponarseurasia.org/memo/can-federalism-unite-ukraine-peace-deal (accessed 1 February 2016).

Hamilton, D.S. 2010. Shoulder to Shoulder: Forging a Strategic US-EU Partnership. Center for Transatlantic Relations, The Paul H. Nitze School of Advanced International Studies, Johns Hopkins University.

Haukkala, H. 2008a. 'A norm-maker or a norm-taker? The changing normative parameters of Russia's place in Europe'. In T. Hopf (ed.), Russia's European Choice. New York: Palgrave Macmillan, pp.35-56.

Haukkala, H. 2008b. 'The European Union as a regional normative hegemon: the case of European neighbourhood policy'. Europe-Asia Studies, 60(9): 1601-22.

Haukkala, H. 2009a. 'From zero-sum to win-win? The Russian challenge to the EU's Eastern neighborhood policies'. SIEPS European Policy Analysis, 12(9): 1-11.

Haukkala, H. 2009b. 'Lost in translation? Why the EU has failed to influence Russia's development'. Europe-Asia Studies, 61(10): 1757-75.

Haukkala, H. 2010. The EU-Russia Strategic Partnership: The Limits of Post-sovereignty in International Relations. Abingdon, UK: Routledge.

Haukkala, H. 2015. 'From cooperative to contested Europe? The conflict in Ukraine as a culmination of a long-term crisis in EU-Russia relations'. Journal of Contemporary European Studies, 23(1): 25-40.

Hettne, B. and Söderbaum, F. 2005. 'Civilian power or soft imperialism? EU as a global actor and the role of interregionalism'. European Foreign Affairs Review, 10(4): 535-52.

Hillion, C. 1998. 'Partnership and cooperation agreements between the EU and the new independent states of the ex-Soviet Union'. European Foreign Affairs Review, 3(3): 399-420 (accessed 12 December 2014).

Hofmann, S.C. 2011. 'Why institutional overlap matters: CSDP in the European security architecture'. JCMS: Journal of Common Market Studies, 49(1): 101-20.

Holsti, K.J. 1970. 'National role conceptions in the study of foreign policy'. International Studies Quarterly, 14(3): 233-309.

Hopf, T. 1999. Understandings of Russian Foreign Policy. University Park, PA: Pennsylvania State University Press.

Hopf, T. 2002. Social Construction of International Politics: Identities and 
Foreign Policies, Moscow, 1955 and 1999. New York: Cornell University Press.

Hopf, T. 2005. 'Identity, legitimacy, and the use of military force: Russia's great power identities and military intervention in Abkhazia'. Review of International Studies, 31(S1): 225-43.

Hopf, T. 2008. 'Introduction'. In T. Hopf (ed.), Russia's European Choice. Basingstoke, UK: Palgrave Macmillan, pp. 1-10.

Howorth, J. 2010. 'The EU as a global actor: grand strategy for a global grand bargain?' JCMS: Journal of Common Market Studies, 48(3): $455-74$.

Hudson, V. 2005. 'Foreign policy analysis: actor-specific theory and the ground of international relations'. Foreign Policy Analysis, 1(1): $1-30$.

Hughes, J. 2006. 'EU relations with Russia: partnership or asymmetric interdependency?' In N. Casarini and C. Muzu (eds), The EU's Foreign Policy in an Evolving International System: The Road to Convergence. London: Palgrave Macmillan, p. 76-94.

Huntington, S.P. 1993. 'The clash of civilizations?' Foreign Affairs, 72(3): 22-49.

Huntington, S.P. 1999. 'The lonely superpower'. Foreign Affairs, 78(2): $35-49$.

Hutton, W. 2002. 'Time to stop being America's lap-dog'. Guardian, 17 February. Available: https://www.theguardian.com/world/2002/feb/17/ eu.foreignpolicy (accessed 23 June 2014).

Hyde-Price, A. 2008. 'A "tragic actor"? A realist perspective on "ethical power Europe"'. International Affairs, 84(1): 29-44.

IEA. 2000. National Gas Information 2000. Available: http://www.oecdilibrary.org/docserver/download/6100121e.pdf?expires $=1441859908 \& \mathrm{i}$ $\mathrm{d}=\mathrm{id} \&$ accname $=$ ocid177592\&checksum $=35$ A55B8A602D3F7A70391 A5F7DAFE00A (accessed 23 June 2014).

IEA. 2012. National Gas Information 2012. Available: http://www.oecdilibrary.org/docserver/download/6112171e.pdf?expires $=1441860196 \& \mathrm{i}$ $\mathrm{d}=\mathrm{id} \&$ accname $=$ ocid $177592 \&$ checksum $=74859$ C66E94ECAAC $83 \mathrm{C} 1$ 5217EC81B952 (accessed 23 June 2014).

Ikenberry, G.J. 2004. 'Illusions of empire - defining the new American order'. Foreign Affairs, 83(2): 144-54.

Interfax-Ukraine. 2013. 'Ukraine, EU agreed on next steps for speedy signing of Association Agreement - Fule'. Interfax-Ukraine, 12 December. Available: http://en.interfax.com.ua/news/general/181526. html (accessed 1 February 2016).

Interfax-Ukraine. 2014. '200 servicemen and law-enforcers killed during anti-terrorist operation in Ukraine's east - Security and Defense 
Council'. Interfax-Ukraine, 2 July. Available: http://en.interfax.com.ua/ news/general/211823.html (accessed 1 February 2016).

Irkliyenko, M. 2013. 'EU ambassador in Kyiv: Tymoshenko, Lutsenko among "biggest burdens" for Ukraine'. Kyiv Post, 25 January. Available: http://www.kyivpost.com/content/ukraine/eu-ambassador-in-kyiv-tymo shenko-lutsenko-among-biggest-burdens-for-ukraine-319359.html (accessed 12 August 2015).

Jepperson, R.L., Wendt, A. and Katzenstein, P.J. 1996. 'Norms, identity, and culture in national security'. In P.J. Katzenstein (ed.), The Culture of National Security: Norms and Identity in World Politics. New Directions in World Politics Series. New York: Columbia University Press, pp. 33-75.

Jones, S.G. 2003. 'The European Union and the security dilemma'. Security Studies, 12(3): 114-56.

Jozwiak, R. 2015. 'EU links Russian sanctions to Minsk agreement'. Radio Free Europe, 20 March. Available: http://www.rferl.org/content/ european-union-ukraine-russia-sanctions-brussels-summit/26910898.html (accessed 1 February 2016).

Juneau, T. 2015. Squandered Opportunity: Neoclassical Realism and Iranian Foreign Policy. Stanford, CA: Stanford University Press.

Jupille, J., Caporaso, J.A. and Checkel, J.T. 2003. 'Integrating institutions: rationalism, constructivism, and the study of the European Union'. Comparative Political Studies, 36(1-2): 7-40.

Kaczmarski, M. 2014. 'Domestic power relations and Russia's foreign policy'. Demokratizatsiya: The Journal of Post-Soviet Democratization, 22(3): 383-409.

Kanet, R.E. 2012. 'Russia in the new international order: theories, arguments and debates'. International Politics, 49(4): 393-9.

Karaganov, S. 2010. 'Survival: global politics and strategy'. Survival: Global Politics and Strategy, 52(1): 5-10.

Karatnycky, A. 2005. 'Ukraine's Orange Revolution'. Foreign Affairs, 84(2): 35-52.

Kaveshnikov, N. 2010. 'The issue of energy security in relations between Russia and the European Union'. European Security, 19(4): 585-605.

Kelley, J. 2006. 'New wine in old wineskins: promoting political reforms through the new European Neighbourhood policy'. JCMS: Journal of Common Market Studies, 44(1): 29-55.

Kelly, L. and Zinets, N. 2015. 'Russia's Putin threatens Ukraine with court over $\$ 3$ billion debt'. Reuters, 9 December. Available: http://www. reuters.com/article/us-russia-imf-kremlin-idUSKBN0TS0UD20151209 (accessed 1 February 2016). 
Keohane, R.O. and Nye, J.S. 1973. 'Power and interdependence'. Survival, 15(4): 158-65.

Keukeleire, S. and MacNaughtan, J. 2014. The Foreign Policy of the EU. New York: Palgrave Macmillan.

Khanna, P. 2008. The Second World: Empires and Influence in the New Global Order. New York: Random House.

Kissinger, H. 1957. A World Restored: Metternich, Castlereagh and the Problems of Peace, 1812-22. Boston, MA: Houghton Mifflin.

Kissinger, H.A. 1966. 'Domestic structure and foreign policy'. Daedalus, 95(2): 503-29.

Kitchen, N. 2010. 'Systemic pressures and domestic ideas: a neoclassical realist model of grand strategy formation'. Review of International Studies, 36(1): 117-43.

Kitchen, N. 2012. 'Ideas of power and the power of ideas'. In A. Toje and B. Kunz (eds), Neoclassical Realism in European Politics: Bringing Power Back In. G - Reference, Information and Interdisciplinary Subjects Series. Manchester: Manchester University Press, pp. 79-95.

Konończuk, W. 2013. 'Gas as an instrument of Russian pressure on Ukraine'. OSW Analyses, 30 January. Available: http://www.osw.waw. pl/en/publikacje/analyses/2013-01-30/gas-instrument-russian-pressureukraine (accessed 12 Agusut 2015).

Korduban,P.2010. 'UkrainianPrime MinisterMykolaAzarovreturnsemptyhanded from Moscow'. Eurasia Daily Monitor, 31 March. Available:http:// www.jamestown.org/programs/edm/single/?tx_ttnews $\% 5 \mathrm{Btt}$ news $\% 5 \mathrm{D}=$ $36211 \& \mathrm{cHash}=50 \mathrm{~b} 447 \mathrm{a} 000 \#$. V7KHyU196M8 (accessed 28 August 2014).

Korotich, V. 1991. 'The Ukraine rising'. Foreign Policy, 85(Winter): 73-82.

Krasner, S.D. 2004. 'Sharing sovereignty: new institutions for collapsed and failing states'. International Security, 29(2): 85-120.

Krasnolutska, D., Tanas, O. and Choursina, K. 2013. 'Yanukovych rules out early vote amid Ukraine protests'. Bloomberg, 20 December. Available: http://www.bloomberg.com/news/articles/2013-12-19/ukrainian-leaderrejects-early-elections-after-weeks-of-protests (accessed 28 August 2014).

Kratochvíl, P. and Tulmets, E. 2010. Constructivism and Rationalism in EU External Relations: The Case of the European Neighbourhood Policy. Baden-Baden: Nomos.

Krauthammer, C. 1990. 'The unipolar moment'. Foreign Affairs, 70(1): 23-33.

Kropatcheva, E. 2011. 'Ukraine's foreign policy choices after the 2010 presidential election'. Journal of Communist Studies and Transition Politics, 27(3-4): 520-40.

Kropatcheva, E. 2014. 'He who has the pipeline calls the tune? Russia's 
energy power against the background of the shale "revolutions". Energy Policy, 66: 1-10.

Krotz, U. 2009. 'Momentum and impediments: why Europe won't emerge as a full political actor on the world stage soon'. JCMS: Journal of Common Market Studies, 47(3): 555-78.

Krotz, U. and Maher, R. 2011. 'International relations theory and the rise of European foreign and security policy'. World Politics, 63(3): 548-79.

Krushelnycky, A. 2013. 'The end of Ukraine's balancing act'. Foreign Policy, 6 February. Available: http://foreignpolicy.com/2013/02/06/theend-of-ukraines-balancing-act/ (accessed 28 August 2014).

Kubicek, P. 1994. 'Delegative democracy in Russia and Ukraine'. Communist and Post-Communist Studies, 27(4): 423-41.

Kubicek, P. 2009. 'Problems of post-post-communism: Ukraine after the Orange Revolution'. Democratization, 16(2): 323-43.

Kudelia, S. 2012. 'Ukraine's credibility gap as a perennial foreign policy problem'. Strategie und Sicherheit, 1: 345-56.

Kuzio, T. 2005a. 'From Kuchma to Yushchenko: Ukraine's 2004 presidential elections and the Orange Revolution'. Problems of Post-Communism, 52(2): 29-44.

Kuzio, T. 2005b. 'Neither East nor West: Ukraine's security policy under Kuchma'. Problems of Post-Communism, 52(5): 59-68.

Kuzio, T. 2005c. 'Russian policy toward Ukraine during elections'. Demokratizatsiya: The Journal of Post-Soviet Democratization, 13(4): 491-518.

Kuzio, T. 2010. 'Ukraine's foreign and security policy controlled by Russia'. Eurasia Daily Monitor, 18 October. Available: http://www.jamestown.org/ programs/edm/single/?tx_ttnews $\% 5 B t t \_n e w s \% 5 D=37043 \& c H a s h=6 \mathrm{~d} 4$ 2a97add\#.V7OJcf1961s (accessed 28 August 2014).

Kyiv Post. 2011. 'Yanukovych: Ukraine to develop relations with Customs Union in 3+1 format'. Kyiv Post, 8 July. Available: http://www.kyivpost.com/content/business/yanukovych-ukraine-to-develop-relationswith-custo-108273.html (accessed 28 August 2014).

Kyiv Post. 2013. 'Yanukovych: memorandum on cooperation with EEC helps Ukraine to cooperate with Customs Union'. Kyiv Post, 20 June. Available: http://www.kyivpost.com/content/politics/yanukovych-memo randum-on-cooperation-with-eec-helps-ukraine-to-cooperate-with-cus toms-union-325908.html (accessed 28 August 2014).

Kyiv Post. 2016. 'Gazprom claims against Naftogaz in Stockholm arbitration rise to $\$ 32$ billion'. Kyiv Post, 15 March. Available: http://www. kyivpost.com/article/content/ukraine-politics/gazprom-claims-againstnaftogaz-in-stockholm-arbitration-rise-to-32-billion-409989.html (accessed 20 March 2016). 
Laffan, B. 1998. 'The European Union: a distinctive model of internationalization'. Journal of European Public Policy, 5(2): 235-53.

Lake, D.A. 1999. 'Ulysses's triumph: American power and the new world order'. Security Studies, 8(4): 44-78.

Lally, K. and Young, K. 2011. 'Putin accuses Clinton, U.S. of fomenting election protests'. Washington Post, 8 December. Available: https://www. washingtonpost.com/world/europe/putin-accuses-clinton-us-of-stirringelection-protests/2011/12/08/gIQA0MUDfO_story.html (accessed 20 March 2016).

Larrabee, F.S. 1996. 'Ukraine's balancing act'. Survival, 38(2): 143-65.

Larrabee, F.S. 2010. 'Russia, Ukraine, and Central Europe: the return of geopolitics'. Journal of International Affairs, 63(2): 33.

Larson, D.W. and Shevchenko, A. 2014. 'Russia says no: power, status, and emotions in foreign policy'. Communist and Post-Communist Studies, 47(3): 269-79.

Lavrov, S. 2013. 'State of the Union Russia-EU: prospects for partnership in the changing world'. JCMS: Journal of Common Market Studies, 51(S1): 6-12.

Layne, C. 1993. 'The unipolar illusion: why new great powers will rise'. International Security, 17(4): 5-51.

Layne, C. 2009. 'The waning of US hegemony - myth or reality? A review essay'. International Security, 34(1): 147-72.

Layne, C. 2012. 'This time it's real: the end of unipolarity and the Pax Americana'. International Studies Quarterly, 56(1): 203-13.

Lebow, R.N. 1994. 'The long peace, the end of the cold war, and the failure of realism'. International Organization, 48(2): 249-77.

Legvold, R. 2001. 'Russia's unformed foreign policy'. Foreign Affairs, 80(5): 62-75.

Legvold, R. 2012. Russian Foreign Policy in the Twenty-first Century and the Shadow of the Past. New York: Columbia University Press.

Lelyveld, M. 2015. 'Doubts rise on Russia-China gas deal'. Radio Free Asia, 4 May. Available: http://www.rfa.org/english/commentaries/energy_watch/ doubts-rise-on-russia-china-gas-deal-04062015110032.html (accessed 20 March 2016).

Leonard, M. and Popescu, N. 2007. A Power Audit of EU-Russia Relations. Brussels: European Council on Foreign Relations.

Livingston, S.G. 1992. 'The politics of international agenda-setting: Reagan and North-South relations'. International Studies Quarterly, 36(3): 313-29.

Lo, B. 2008. Vladimir Putin and the Evolution of Russian Foreign Policy. London: Chatham House.

Lo, B. 2009. Medvedev and the New European Security Architecture. London: Centre for European Reform Policy Brief. 
Lomagin, N. 2012. 'Interest groups in Russian foreign policy: the invisible hand of the Russian Orthodox Church'. International Politics, 49(4): 498-516.

Loskot-Strachota, A. and Zachmann, G. 2014. 'Rebalancing the EU-RussiaUkraine gas relationship'. Bruegel Policy Contribution, December. Available: http://bruegel.org/wp-content/uploads/imported/publications/ Rebalancing_the_EU-Russia-Ukraine_gas_relationship.pdf (accessed 12 January 2015).

Lucas, E. 2009. 'EU-Russia relations: between cooperation and confrontation'. European View, 8(2): 217-20.

Luhn, A. 2014. 'Belarus hopes to benefit as host of Ukraine-Russia talks'. Guardian, 26 August. Available: http://www.theguardian.com/ world/2014/aug/26/belarusia-president-lukashenko-benefit-host-ukra ine-russia-talks (accessed 12 January 2015).

Lukin, A. 2015. 'Eurasian great power triangle'. In A. Klieman (ed.), Great Powers and Geopolitics. Dordrecht: Springer, pp. 183-205.

Lukyanov, F. 2008. 'Russia-EU: the partnership that went astray'. EuropeAsia Studies, 60(6): 1107-19.

Lupovici, A. 2009. 'Constructivist methods: a plea and manifesto for pluralism'. Review of International Studies, 35(1): 195-218.

Lynch, A.A.C. 2001. 'The realism of Russia's foreign policy'. Europe-Asia Studies, 53(1): 37-41.

MacFarlane, N. 1999. 'Realism and Russian strategy after the collapse of the USSR'. In E.B. Kapstein and M. Mastanduno (eds), Unipolar Politics Realism and State Strategies After the Cold War. New York: Columbia University Press, pp. 218-60.

MacFarquhar, N.2014. 'GazpromcutsRussia'snaturalgassupplytoUkraine'. New York Times, 16 June. Available: http://www.nytimes.com/2014/06/17/ world/europe/russia-gazprom-increases-pressure-on-ukraine-in-gas-dis pute.html (accessed 12 January 2015).

MacFarquhar, N. and Kramer, A. 2014. 'Praising rebels, Putin toughens tone on Ukraine'. New York Times, 29 August. Available: http://www. nytimes.com/2014/08/30/world/europe/ukraine-conflict.html (accessed 12 January 2015).

Majumdar, D. 2015. 'Europe's 4 deadliest military powers'. The National Interest, 10 February. Available: http://nationalinterest.org/feature/ europes-4-deadliest-military-powers-12214 (accessed 23 September 2015).

Mankoff, J. 2009. Russian Foreign Policy: The Return of Great Power Politics. Rowman \& Littlefield.

Mankoff, J. 2014. 'Russia's latest land grab'. Foreign Affairs, 93(3): 60-8. Manners, I. 2002. 'Normative power Europe: a contradiction in terms?' JCMS: Journal of Common Market Studies, 40(2): 235-58. 
Marchak, D. and Gorchinskaya, K. 2013. 'Russia gives Ukraine cheap gas, $\$ 15$ billion in loans'. Kyiv Post, 17 December. Available: http:// www.kyivpost.com/content/ukraine/russia-gives-ukraine-cheap-gas-15billion-in-loans-333852.html (accessed 12 January 2015).

Martin, S. 1997. 'Beyond the G8, Yeltsin sees his country in the EU'. Irish Times, 24 March. Available: http://www.irishtimes.com/news/beyondthe-g8-yeltsin-sees-his-country-in-the-eu-1.55254 (accessed 12 January 2015).

Martin, W.2015. 'Russiajust froze Ukraine's gassupply in what could be really badnewsforEurope'. Business Insider,25November.Available:http://www. businessinsider.com/gazprom-cuts-off-gas-supplies-to-ukraine-2015-11? $\mathrm{IR}=\mathrm{T}$ (accessed 15 February 2016).

McClory, J. 2013. 'Soft central'. Monocle, 59(6): 46-54.

Mcdonagh, E. 2008. 'Democratization: is democracy promotion effective in Moldova? The impact of European institutions on development of civil and political rights in Moldova'. Democratization, 15(1): $37-41$.

Mearsheimer, J.J. 1990. 'Back to the future: instability in Europe after the Cold War'. International Security, 15(1): 5-56.

Mearsheimer, J.J. 1994. 'The false promise of international institutions'. International Security, 19(3): 5-49.

Melnykovska, I. 2010. 'Ukraine's Energy Policy - Caught between Soviet legacies, Russian leverage and European integration'. In A. Gawrich, A. Franke and J. Windwehr (eds), Resources from Energy as a Curse? Rentierism and Energy Policy in Post-Soviet States. Opladen: Barbara Budrich Publishing, pp. 165-200.

Melnykovska, I., Plamper, H. and Schweickert, R. 2012. 'Do Russia and China promote autocracy in Central Asia?' Asia Europe Journal, 10(1): 75-89.

Menon, A. 2014. 'The JCMS Annual Review Lecture divided and declining? Europe in a changing world'. JCMS: Journal of Common Market Studies, 52(Annual Review): 5-24.

Meunier, S. and Nicolaidis, K. 2006. 'The European Union as a conflicted trade power'. Journal of European Public Policy, 13(6): 906-25.

Mielniczuk, F. 2013. 'BRICS in the contemporary world: changing identities, converging interests'. Third World Quarterly, 34(6): 1075-90.

Miller, B. 2002. When Opponents Cooperate: Great Power Conflict and Collaboration in World Politics. Ann Arbor, MI: University of Michigan Press.

Minchenko, Е. 2010. 'Политолог: В российском руководстве есть “политбюро" и “ЦК”. Росбалт, 9 October. Available: http://www. rosbalt.ru/moscow/2010/12/09/799055.html (accessed 12 January 2015). 
Ministry of Energy of the Russian Federation, The. 2010. Energy Strategy of Russia for the Period up to 2030. Available: http:// www.energystrategy.ru/projects/docs/ES-2030_(Eng).pdf (accessed 23 September 2015).

Ministry of Foreign Affairs of the Russian Federation, The. 2013a. Reply by the Official Representative of the Russian Ministry of Foreign Affairs Alexander Lukashevich to the Mass Media's Question Regarding Statements of Representatives of the European Commission (EC) Concerning the Prospects of Relations with Ukraine and Member States of the Customs Union (CU). Available: http://archive.mid.ru//brp_4. nsf/0/CD9B0F104FCF668344257BD7005237C7 (accessed 23 September 2015).

Ministry of Foreign Affairs of the Russian Federation, The. 2013b. Interview by the Russian Foreign Minister Sergey Lavrov to Russia Today TV-channel, Moscow, 24 December. Available: http://www.mid.ru/en_GB/foreign_ policy/news/-/asset_publisher/cKNonkJE02Bw/content/id/82586/pop_ up?_101_INSTANCE_cKNonkJE02Bw_viewMode=print\&_101_INS TANCE_cKNonkJE02Bw_qrIndex =0 (accessed 23 September 2015).

Mintz, A. and DeRouen Jr, K. 2010. Understanding Foreign Policy Decision Making. Cambridge: Cambridge University Press.

Molchanov, M. 2015. '(Un)solving Ukraine's conflict'. Open Democracy, 16 July. Available: https://www.opendemocracy.net/od-russia/mikhailmolchanov/unsolving-ukraine $\%$ E2\%80\%99s-conflict (accessed 23 February 2016).

Moravcsik, A. 1993. 'Preferences and power in the European Community: a liberal intergovernmentalist approach'. JCMS: Journal of Common Market Studies, 31(4): 473-524.

Moravcsik, A. 1999. "Is something rotten in the state of Denmark?" Constructivism and European integration'. Journal of European Public Policy, 6(4): 669-81.

Moravcsik, A. 2003. 'Striking a new transatlantic bargain'. Foreign Affairs, 82(4): 74-89.

Morgenthau, H.J. 1967. 'To intervene or not to intervene'. Foreign Affairs, 45(3): 425-36.

Morgenthau, H.J. 1969. A New Foreign Policy for the United States. New York: Praeger.

Morozov, V. 2009. 'Obsessed with identity: the IR in post-Soviet Russia'. Journal of International Relations and Development, 12(2): 200-5.

Morozova, N. 2009. 'Geopolitics, Eurasianism and Russian foreign policy under Putin'. Geopolitics, 14(4): 667-86.

MoscowTimes. 2013. 'Ukrainerefusestopay\$7blnfinetoGazprom'. Moscow Times, 25February. Available:http:/www.themoscowtimes.com/business/ 
article/ukraine-refuses-to-pay-7bln-fine-to-gazprom/475994.html (accessed 12 January 2015).

Moshes, A. 2012. 'Russia's European policy under Medvedev: how sustainable is a new compromise?' International Affairs, 88(1): 17-30.

Moshes, A. 2013. 'Will Ukraine join (and save) the Eurasian Customs Union?' Ponars Eurasia, Policy memo 247. Available: http://www.ponar seurasia.org/memo/will-ukraine-join-and-save-eurasian-customs-union (accessed 12 January 2015).

Motyl, A.J. 2014. 'Putin's Zugzwang: the Russia-Ukraine standoff'. World Affairs, 177(2): 58-65.

Mroz, J.E. and Pavliuk, O. 1996. 'Ukraine: Europe's linchpin'. Foreign Affairs, 75(3): 52-62.

Müller, M. 2011. 'New kids on the block: the rise of the BRIC and the reconfiguration of global economic ties'. European Researcher, 12(15): 1615-25.

Naftogaz. 2015. 'Gas imports in Ukraine, 2013-2014'. Facts and Figures, 31 January. Available: http://naftogaz-europe.com/article/en/ Gasimports2014 (accessed 23 September 2015).

Naftogaz. 2016. 'Ukraine purchased 63\% of its imported gas in Europe in 2015'. Facts and Figures, 1 February. Available: http://naftogaz-europe. com/article/en/gasimport2015eng (accessed 1 March 2016).

Natural Gas Europe. 2013. 'Ukraine Threatens to Quit Energy Group Over Russian Dispute'. 25 February. Available: http://www.naturalgaseurope. com/ukraine-threatens-to-quit-over-shale (accessed 12 January 2015).

Natural Gas Europe. 2016. 'Ukraine and Iran Develop Gas Cooperation'. 8 March. Available: http://www.naturalgaseurope.com/ukraine-andiran-strengthen-gas-cooperation-28543 (accessed 1 March 2016).

Neumann, I.B. 2002. Russia and the Idea of Europe: A Study in Identity and International Relations. London: Routledge.

Nikitin, A. 2008. 'Russian foreign policy in the fragmented post-Soviet space'. International Journal on World Peace, 25(2): 7-31.

Nilsson, M. and Silander, D. 2016. 'Democracy and security in the EU's Eastern Neighborhood? Assessing the ENP in Georgia, Moldova, and Ukraine'. Democracy and Security, 12(1): 44-61.

Nord Stream AG. 2006. 'The pipeline through the Baltic Sea is a priority energy project for the European Union'. Press hotline, 4 October. Available: http://www.nord-stream.com/press-info/pressreleases/the-pipeline-through-the-baltic-sea-is-a-priority-energy-projectfor-the-european-union-125/ (accessed 1 March 2016).

Nord Stream AG. 2012a. 'Next step in the potential extension of Nord Stream'. Press hotline, 8 October. Available: http://www.nord-stream.com/ press-info/press-releases/next-step-in-the-potential-extension-of-nord-str eam-426/ (accessed 1 March 2016). 
Nord Stream AG. 2012b. 'We deliver: Nord Stream's twin pipelines come on stream'. Press hotline, 8 October. Available: http://www.nord-stream.com/ press-info/press-releases/we-deliver-nord-streams-twin-pipelines-comeon-stream-425/ (accessed 1 March 2016).

Nye, J.S. 1990. 'Soft power'. Foreign Policy, 80: 153-71.

Nye, J.S. 2004. Soft Power: The Means to Success in World Politics. New York: Public Affairs.

Nygren, B. 2012. 'Using the neo-classical realism paradigm to predict Russian foreign policy behaviour as a complement to using resources'. International Politics, 49(4): 517-29.

Oettinger, G. 2010. 'Speech of Commissioner Oettinger at the International Odessa Forum'. European Commission, Press release, 27 July. Available: http://europa.eu/rapid/press-release_SPEECH-10-402_en.htm (accessed 23 September 2015).

Oettinger, G. 2014. 'European Energy Security Strategy: key priorities and actions'. European Commission, Press release, 25 June. Available: http://europa.eu/rapid/press-release_SPEECH-14-505_en.htm (accessed 23 September 2015).

Orbie, J. 2006. 'Civilian power Europe'. Cooperation and Conflict, 41(1): 123-28.

Orrtung, R. and Walker, C. 2015. 'Putin's frozen conflicts'. Foreign Policy, 13 February. Available: http://foreignpolicy.com/2015/02/13/putinsfrozen-conflicts/ (accessed 23 September 2015).

Partyof theRegions. 2013. Mykola Azarov: '3 + 1'Formulaof Relations Between Ukraine, CU Starts Working. Available: http://partyofregions.ua/en/ news/52440628c4ca42fe0e0000a5\#sthash.WpnD6AxX.dpuf (accessed 23 September 2015).

Petrov, N. and Ryabov, A. 2006. 'Russia's role in the Orange Revolution'. In A. Åslund and M. McFaul (eds), Revolution in Orange: The Origin of Ukraine's Democratic Breakthrough. Washington, DC: Carnegie Endowment, pp. 145-64.

Petrov, R. 2014. 'European legal space and application of the European Union's "energy acquis" in Ukraine and Moldova'. In C. Cambini and A. Rubino (eds), Regional Energy Initiatives: MedReg and the Energy Community. Abingdon, UK: Routledge, pp. 175-91.

Petrovic, M. 2013. The Democratic Transition of Post-communist Europe: In the Shadow of Communist Differences and Uneven Europeanisation. Basingstoke, UK: Palgrave Macmillan.

Pifer, S. 2014. 'Poroshenko Signs EU-Ukraine Association Agreement', Brookings, 27 June. Available: http://www.brookings.edu/blogs/up-front/ posts/2014/06/27-poroshenko-signs-eu-ukraine-association-agreementpifer (accessed 12 January 2015). 
Pipelines International. 2010. 'The Urengoy-Pomary-Uzhgorod Pipeline: a Cold War pipeline'. Pipelines International, September. Available: $\mathrm{http} / / /$ pipelinesinternational.com/news/the_urengoy_pomary_uzhgorod_ pipeline_a_cold_war_pipeline/043753/ (accessed 12 January 2015).

Pirani, S. 2007. Ukraine's Gas Sector. Oxford: Oxford Institute for Energy Studies.

Pirani, S., Stern, J.P. and Yafimava, K. 2009. The Russo-Ukrainian Gas Dispute of January 2009: A Comprehensive Assessment. Oxford: Oxford Institute for Energy Studies.

Plucinska, J. 2015. 'Ukrainian and NATO sign defense agreement'. Time, 17 December. Available: http://time.com/4153032/ukraine-natocooperation-agreement/.

Pollack, M.A. 2001. 'International relations theory and European integration'. JCMS: Journal of Common Market Studies, 39(2): 221-44.

Popescu, N. 2013. 'The Russia-Ukraine trade spat'. European Union Institute for Security Studies, August: 1-2.

Popescu, N. 2014. 'Eurasian Union: the real, the imaginary and the likely'. EU ISS: Chaillot Papers, 132(September).

Posen, B.P. 2009. 'Emerging multipolarity: why should we care?' Current History, 108(721): 347-52.

President of Russia. 2005. Annual Address to the Federal Assembly of the Russian Federation. Available: http://archive.kremlin.ru/eng/ speeches/2005/04/25/2031_type70029type82912_87086.shtml (accessed 12 January 2015).

President of Russia. 2008. The Foreign Policy Concept of the Russian federation. Available: http://archive.kremlin.ru/eng/text/docs/2008/07/204750. shtml (accessed 12 January 2015).

President of Russia. 2009. Joint News Conference Following RussianGerman Intergovernmental Consultations. Available: http://en.kremlin. $\mathrm{ru} /$ events/President/transcripts/4820 (accessed 12 January 2015).

President of Russia. 2010a. Joint News Conference with President of Ukraine Viktor Yanukovych. Available: http://en.kremlin.ru/events/ President/transcripts/7518 (accessed 12 January 2015).

President of Russia. 2010b. Speech at Russian-Ukrainian Economic Forum. Available: http://archive.kremlin.ru/eng/speeches/2010/05/18/1900_type 82914type84779_226137.shtml (accessed 12 January 2015).

President of Russia. 2012a. Meeting with President of Ukraine Viktor Yanukovych. Available:http://en.kremlin.ru/events/President/news/16698 (accessed 12 January 2015).

President of Russia. 2012b. News Conference of Vladimir Putin. Available: http://en.kremlin.ru/events/President/news/17173 (accessed 12 January 2015). 
President of Russia. 2012c. Meeting with Gazprom CEO Alexei Miller. Available: http://en.special.kremlin.ru/catalog/persons/149/events/14259 (accessed 12 January 2015).

President of Russia. 2013a. Telephone Conversation with President of Ukraine Viktor Yanukovych. Available: http://en.kremlin.ru/events/ President/news/19043 (accessed 12 January 2015).

President of Russia. 2013b. Press Statement Following a Meeting of Russian-Ukrainian Interstate Commission. Available: http://en.kremlin. ru/events/President/transcripts/19854 (accessed 12 January 2015).

President of Russia.2013c. Meeting of the ValdaiInternationalDiscussion Club. Available: http://en.kremlin.ru/events/President/news/19243 (accessed 12 January 2015).

President of Russia. 2013d. Meeting with President of Ukraine Viktor Yanukovych. Available: http://en.kremlin.ru/events/President/ news/19849 (accessed 12 January 2015).

President of Russia. 2013e. Presidential Address to the Federal Assembly. Available: http://en.kremlin.ru/events/President/news/19825 (accessed 12 January 2015).

President of Russia. 2014a. Meeting with President of the People's Republic of China Xi Jinping. Available: http://en.kremlin.ru/events/President/ news/46598 (accessed 12 January 2015).

President of Russia. 2014b. Direct Line with Valdimir Putin. Available: http:// en.special.kremlin.ru/events/President/news/20796 (accessed 12 January 2015).

President of Russia. 2015. Free Trade Zone Agreement with Ukraine Suspended. Available: http://en.kremlin.ru/acts/news/50969 (accessed 1 March 2016).

Pridham, G. 2000. The Dynamics of Democratization: A Comparative Approach. London: Continuum.

Prime Minister of Russia. 2011. Prime Minister Vladimir Putin Takes Part in the VTB Capital 'Russia Calling!' Investment Forum. Available: http:// archive.premier.gov.ru/eng/events/news/16653/(accessed 12 January 2015).

Puglisi, R. 2003. 'Clashing agendas? Economic interests, elite coalitions and prospects for co-operation between Russia and Ukraine'. EuropeAsia Studies, 55(6): 827-45.

Putin, V. 2011. 'Новый интеграционный проект для Евразии - будущее, которое рождается сегодня'. Izvestia Daily, 3 October. Available: http://izvestia.ru/news/502761\#ixzz31ILZDFvK (accessed 12 January 2015).

Rathbun, B. 2008. 'A rose by any other name: neoclassical realism as the logical and necessary extension of structural realism'. Security Studies, 17(2): 294-321. 
Research Europe. 2011. 'Günther Oettinger, EU Commissioner for Energy'. Research Europe. Available: http://webcache.googleusercontent.com/ search?q=cache:hWMpKA6MRwIJ:www.research-europe.com/index. $\mathrm{php} / 2011 / 08 /$ gunther-oettinger-eu-commissioner-for-energy $/+\& \mathrm{~cd}=1 \&$ $\mathrm{hl}=\mathrm{en} \& \mathrm{ct}=\mathrm{clnk} \& \mathrm{gl}=\mathrm{nz}$ (accessed 12 January 2015).

Rettman, A. 2014. 'EU and Ukraine suspend trade pact', EU Observer, 12 September. Available: https://euobserver.com/foreign/125601 (accessed 12 January 2015).

Rettman, A. 2015a. 'EU-brokered talks on Ukraine: towards a Minsk 3?' EU Observer, 2 October. Available: https://euobserver.com/ foreign/130529 (accessed 19 December 2015).

Rettman, A. 2015b. 'Italy clarifies position on Russia sanctions'. EU Observer, 15 December. Available: https://euobserver.com/ foreign/131514 (accessed 19 December 2015).

Reuters. 2015. 'EU foreign policy chief's paper on EU-Russia relations - text'. Reuters, 15 January. Available: http://www.reuters.com/ article/ukraine-crisis-eu-russia-idUSL6N0UU2T820150115 (accessed 19 December 2015).

Risse, T. 2005. 'Neofunctionalism, European identity, and the puzzles of European integration'. Journal of European Public Policy, 12(2): 291-309.

Risse, T. and Wiener, A. 1999. "Something rotten" and the social construction of social constructivism: a comment on comments'. Journal of European Public Policy, 6(5): 775-82.

Rittberger, V. 2004. Approaches to the Study of Foreign Policy Derived from International Relations Theories. Tübingen: University of Tübingen.

Robinson, D. 2016. 'Dutch reject EU-Ukraine trade deal'. Financial Times, 7 April. Available: http://www.ft.com/intl/cms/s/0/3efd835a-fc2f11e5-b3f6-11d5706b613b.html\#axzz46VJKnUIO (accessed 19 April 2016).

Rosamond, B. 2007. 'New theories of European integration'. In M. Cini (ed.), European Union Politics. Oxford: Oxford University Press, pp. 117-36.

Rosato, S. 2011. 'Europe's troubles'. International Security, 35(4): 45-86.

Rose, G. 1998. 'Neoclassical realism and theories of foreign policy'. World Politics, 51(1): 144-72.

RT. 2013. "Trade "suicide": Russia prepares to tighten borders if Ukraine signs on with EU'. RT, 19 August. Available: http://www.rt.com/busi ness/trade-war-ukraine-russia-656/ (accessed 23 September 2015).

RT. 2014. 'Russia has no intention to send troops into Ukraine - Lavrov'. $R T, 29$ March. Available: http://www.rt.com/news/lavrov-interviewukraine-russia-065/ (accessed 23 September 2015). 
RT. 2016. 'Italy and Hungary against automatic renewal of anti-Russian sanctions'. RT, 15 March. Available: https://www.rt.com/business/335647russia-hungary-italy-sanctions/ (accessed 19 April 2016).

Runner, P. 2008. 'EU-Ukraine summit masks disappointment'. EU Observer, 9 September. Available: https:/euobserver.com/foreign/26711 (accessed 23 September 2015).

Rutland, P. 2008. 'Russia as an energy superpower'. New Political Economy, 13(2): 203-10.

Rynning, S. 2005. 'Return of the Jedi: realism and the study of the European Union'. Politique européenne, 17(3): 10-33.

Rynning, S. 2011. 'Realism and the common security and defence policy'. JCMS: Journal of Common Market Studies, 49(1): 23-42.

Sakwa, R. 2008. "New Cold War" or twenty years' crisis? Russia and international politics'. International Affairs, 2, 241-67.

Sakwa, R. 2010a. Russia and Turkey: Rethinking Europe to Contest Outsider Status. Paris: IFRI Russia/NIS Center.

Sakwa, R. 2010b. 'The dual state in Russia'. Post-Soviet Affairs, 26(3): 185-206.

Sakwa, R. 2012. 'Sovereignty and democracy: constructions and contradictions in Russia and beyond'. Regional Studies of Russia, Eastern Europe, and Central Asia, 1(1): 3-27.

Satter, D. 2014. 'The last gasp of empire: Russia's attempts to control the media in the former Soviet Republics'. Center for International Media Assistance, 8 January. Available: http://www.cima.ned.org/wp-content/ uploads/2015/01/CIMA-Russia-report_David-Satter.pdf (accessed 19 April 2016).

Schimmelfennig, F. and Sedelmeier, U. 2002. 'Theorizing EU enlargement: research focus, hypotheses, and the state of research'. Journal of European Public Policy, 9(4): 500-28.

Schimmelfennig, F. and Sedelmeier, U. 2004. 'Governance by conditionality: EU rule transfer to the candidate countries of Central and Eastern Europe'. Journal of European Public Policy, 11(4): 661-79.

Schimmelfennig, F. and Thomas, D.C. 2009. 'Normative institutionalism and EU foreign policy in comparative perspective'. International Politics, 46(4): 491-504.

Schweller, R.L. 1994. 'Bandwagoning for profit: bringing the revisionist state back in'. International Security, 19(1): 72-107.

Schweller, R.L. 2004. 'Unanswered threats: a neoclassical realist theory of underbalancing'. International Security, 29(2): 159-201.

Selden, Z. 2010. 'Power is always in fashion: state-centric realism and the European security and defence policy'. JCMS: Journal of Common Market Studies, 48(2): 397-416. 
Serfaty, S. 2011. 'Moving into a post-Western world'. Washington Quarterly, 34(2): 7-23.

Shapiro, J. and Witney, N. 2009. Towards a Post-American Europe: A Power Audit of EU-US Relations. Brussels: European Council on Foreign Relations.

Shchetko, N. 2014. 'Russia warns Ukraine over closer EU ties'. Wall Street Journal, 15 December. Available: http://www.wsj.com/articles/russiarevives-threats-of-higher-trade-tariffs-on-ukraine-goods-1418649531 (accessed 19 April 2016).

Shennan, J.H. 2013. International Relations in Europe, 1689-1789. London: Routledge.

Sherr, J. 1997. 'Russia-Ukraine rapprochement? The Black Sea fleet accords'. Survival, 39(3): 33-50.

Sherr, J. 2011. 'Hard power in the Black Sea region: a dreaded but crippled instrument'. Southeast European and Black Sea Studies, 11(3): 279-98.

Shevchenko, M. 2015. 'Ukraine's trade representative: Russian embargo not to affect our economy'. UNIAN, 24 October. Available: http://www. unian.info/economics/1162418-ukraines-trade-representative-russianembargo-not-to-affect-our-economy.html (accessed 19 April 2016).

Shevtsova, L. 2015. 'Forward to the past in Russia'. Journal of Democracy, 26(2): 22-36.

Shumylo-Tapiola, O. 2012. 'Ukraine at the crossroads: between the EU DCFTA \& Customs Union'. Russie. NEI. Reports No. 11. Available: $\mathrm{http}$ ://carnegieendowment.org/files/Ukraine_at_the_CrossroadsBetween_the_EU_DCFTA_Customs_Union.pdf (accessed 19 April 2016).

Sikorski, R. 2009. 'The EU's "Eastern Partnership" with former Soviet states holds the key to relations with Russia', Europe's World, 1 June. Available: http://europesworld.org/2009/06/01/the-eus-eastern-partner ship-with-former-soviet-states-holds-the-key-to-relations-with-russia/\# . VfHr91WqpBc (accessed 12 June 2015).

Simão, L. 2012. 'Do leaders still decide? The role of leadership in Russian foreign policymaking'. International Politics, 49(4): 482-97.

Simão, L. 2014. 'The new European bipolarity'. Open Democracy, 14 March. Available: https://www.opendemocracy.net/can-europe-make-it/ lic $\% \mathrm{C} 3 \% \mathrm{ADnia}-\operatorname{sim} \% \mathrm{C} 3 \% \mathrm{~A} 3 \mathrm{o} /$ new-european-bipolarity (accessed 12 June 2015).

Simons, G. 2014. 'Russian public diplomacy in the 21st century: structure, means and message'. Public Relations Review, 40(3): 440-9.

SIPRI. Databases. Available: https://www.sipri.org/databases (accessed 1 March 2016). 
Smith, K.E. 1999. The Making of EU Foreign Policy: The Case of Eastern Europe. Basingstoke, UK: Palgrave Macmillan.

Smith, K.E. 2005. 'Beyond the civilian power EU debate'. Politique européenne, 3: 63-82.

Smith, K.E. 2012. 'India's identity and its global aspirations'. Global Society, 26(3): 369-85.

Smith, M.E. 2003. 'The framing of European foreign and security policy: towards a post-modern policy framework?' Journal of European Public Policy, 10(4): 556-75.

Smith, M.J. 1990. Realist Thought from Weber to Kissinger. Baton Rouge, LO: Louisiana State University Press.

Smith, N.R. 2012. 'The EU's two-track promotion of democracy in its Eastern Neighbourhood: examining the case of Armenia'. Asia-Pacific Journal of EU Studies, 10(1): 25-50.

Smith, N.R. 2014. 'The underpinning realpolitik of the EU's policies towards Ukraine: an analysis of norms and interests in the EUUkraine Association Agreement'. European Foreign Affairs Review, 19(4): 581-96.

Smith, N.R. 2015. 'The EU and Russia's conflicting regime preferences in Ukraine: assessing regime promotion strategies in the scope of the Ukraine crisis'. European Security, 24(4): 525-40.

Smith, N.R. 2016. 'The EU under a realist scope: employing a neoclassical realist framework for the analysis of the EU's Deep and Comprehensive Free Trade Agreement offer to Ukraine'. International Relations, 30(1): $29-48$.

Sobczyk, M.M. 2015. 'Ukraine president tells Poles he wants EU, NATO Membership'. Wall Street Journal, 17 December. Available: http://blogs. wsj.com/brussels/2014/12/17/ukraine-president-tells-poles-he-wants-eunato-membership/ (accessed 12 June 2015).

Solonenko, I. 2009. 'External democracy promotion in Ukraine: the role of the European Union'. Democratization, 16(4): 709-31.

Sputnik. 2015. 'Kremlin confirms fall meeting between Putin, Erdogan on Turkish Stream'. Sptunik News, 31 July. Available: http://sputniknews. com/business/20150731/1025254393.html (accessed 23 Septemeber 2015).

Stegen, K.S. 2011. 'Deconstructing the "energy weapon": Russia's threat to Europe as case study'. Energy Policy, 39(10): 6505-13.

Stent, A.E. 2008. 'Restoration and revolution in Putin's foreign policy'. Europe-Asia Studies, 60(6): 1089-106.

Sterling-Folker, J. 1997. 'Realist environment, liberal process, and domesticlevel variables'. International Studies Quarterly, 41(1): 1-25.

Sterling-Folker, J. 2002. 'Realism and the constructivist challenge: rejecting, reconstructing, or rereading'. International Studies Review, 4(1): 73-97. 
Stern, J. 2006. 'Natural gas security problems in Europe: the RussianUkrainian crisis of 2006'. Asia-Pacific Review, 13(1): 32-59.

Stern, J., Pirani, S. and Yafimava, K. 2015. 'Does the cancellation of South Stream signal a fundamental reorientation of Russian gas export policy?' Journal of Self-Governance \& Management Economics, 3(2): $30-49$.

Sushko, O. 2003. 'From the CIS to the SES. A new integrationist game in Post-Soviet space'. Center for Peace, Conversion and Foreign Policy of Ukraine.

Suzuki, S. 2015. 'The rise of the Chinese "Other" in Japan's construction of identity: is China a focal point of Japanese nationalism?' The Pacific Review, 28(1): 95-116.

Szeptycki, A. 2008. 'Trade relations between the Russian Federation and Ukraine'. Polish Institute of International Affairs. Available: http://www. isn.ethz.ch/Digital-Library/Publications/Detail/?ots591=0c54e3b3-1e9cbe1e-2c24-a6a8c7060233\&lng=en\&id=93310 (accessed 12 June 2015).

Taliaferro, J.W. 2006. 'State building for future wars: neoclassical realism and the resource-extractive state'. Security Studies, 15(3): 464-95.

Taliaferro, J.W., Lobell, S.E. and Ripsman, N.M. 2009. 'Introduction: neoclassical realism, the state and foreign policy'. In S.E. Lobell, N.M. Ripsman and J.W. Taliaferro (eds), Neoclassical Realism, the State, and Foreign Policy. Cambridge: Cambridge University Press, pp. 1-41.

TASS. 2014. 'Lavrov: Russia cannot lose Ukraine'. TASS Russian News Agency, 19 October. Available: http://tass.ru/en/russia/755207 (accessed 12 June 2015).

TASS. 2016. 'Russia won't negotiate Crimea's return with anyone - FM'. TASS Russian News Agency, 26 January. Available: http://tass.ru/en/ politics/852238 (accessed 1 March 2016).

Telegraph. 2015. 'Minsk Two offers hope but not peace'. Telegraph, 13 February. Available: http://www.telegraph.co.uk/news/worldnews/ europe/ukraine/11409537/Minsk-Two-offers-hope-but-not-peace.html (accessed 12 June 2015).

Telò, M. 2012. 'Conclusions: state and new multilateralism facing an unprecedented multipolar world'. In M. Telò (ed.), State, Globalization and Multilateralism. Dordrecht: Springer, pp. 159-82.

Thomas, D.C. 2009. 'Explaining the negotiation of EU foreign policy: normative institutionalism and alternative approaches'. International Politics, 46(4): 339-57.

Thomas, D.C. and Tonra, B. 2012. 'To what ends EU Foreign Policy? Contending approaches to the Union's diplomatic objectives and representation'. The Hague Journal of Diplomacy, 7(1): 11-29.

Thorun, C. 2009. Explaining Change in Russian Foreign Policy: The Role 
of Ideas in Post-Soviet Russia's Conduct Towards the West. Basingstoke, UK: Palgrave Macmillan.

Tocci, N. and Alcaro, R. 2014. 'Rethinking transatlantic relations in a multipolar era'. International Politics, 51(3): 366-89.

Toje, A. 2008. 'The consensus-expectations gap: explaining Europe's ineffective foreign policy'. Security Dialogue, 39(1): 121-41.

Toje, A. 2011. 'The European Union as a small power'. JCMS: Journal of Common Market Studies, 49(1): 43-60.

Toje, A. and Kunz, B. 2012. 'Introduction: neoclassical realism in Europe'. In A. Toje and B. Kunz (eds), Neoclassical Realism in European Politics: Bringing Power Back In. Manchester: Manchester University Press, pp. 1-16.

Tonra, B. and Christiansen, T. 2004. Rethinking European Union Foreign Policy. Manchester: Manchester University Press.

Treisman, D. 2007. 'Putin's silovarchs'. Orbis, 51(1): 141-53.

Trenin, D. 2006. 'Russia leaves the West'. Foreign Affairs, 85(4): 87-96.

Trenin, D. 2007. 'Russia redefines itself and its relations with the West'. Washington Quarterly, 30(2): 95-105.

Tsukanova, A. 2016. 'Ukraine: in search of brainstorm solutions to conflict'. Strategic Culture Foundation, 20 January. Available: http://www.strategicculture.org/pview/2016/01/20/ukraine-taken-by-brainstorm.html (accessed 1 March 2016).

Tsygankov, A.P. 2007. 'Finding a civilisational idea: "West," Eurasia," and "Euro-East" in Russia's foreign policy'. Geopolitics, 12(3): 375-99.

Tsygankov, A.P. 2010. Russia's Foreign Policy: Change and Continuity in National Identity. London: Rowman \& Littlefield.

Tsygankov, A.P. 2012. 'Change and continuity in Russia's foreign policy'. Russian Analytical Digest, 109: 9-11.

Tsygankov, A.P. 2013. 'Moscow's soft power strategy'. Current History, 112(756): 259.

Tusk, D. 2014. 'A united Europe can end Russia's energy stranglehold'. FinancialTimes, 21 April.Available:http://www.ft.com/cms/s/0/91508464c661-11e3-ba0e-00144feabdc0.html\#axzz31ILW0Tj7 (accessed 1 March 2016).

Ukraine Today. 2014. 'Poroshenko discusses European Energy Union plans'. Ukraine Today, 15 November. Available: http://uatoday.tv/ politics/poroshenko-discusses-european-energy-union-plans-391864.html (accessed 1 March 2016).

UKRINFORM. 2012. 'Yanukovych notes importance of creating trilateral gas consortium'. UKRINFORM, 4 February. Available: http:// www.ukrinform.ua/eng/news/yanukovych_notes_importance_of_creat ing_trilateral_gas_consortium (accessed 1 March 2016). 
United Nations. 1995. 1994 International Trade Statistics Yearbook. New York: United Nations.

United Nations. 2005. 2004 International Trade Statistics Yearbook. New York: United Nations.

United Nations. 2013. 2012 International Trade Statistics Yearbook. New York: United Nations.

Vahtra, P. 2009. 'Energy security in Europe in the aftermath of 2009 RussiaUkraine gas crisis'. In K. Liuhto (ed.), EU-Russia Gas Connection: Pipes, Politics and Problems. Turku: Turku School of Economics, pp. $158-65$.

Van Evera, S. 1990. 'Primed for peace: Europe after the Cold War'. International Security, 15(3): 7-57.

Varfolomeyev, O. 2016. 'Trade war with Russia prompts Ukraine to look for new markets, transit routes'. Eurasian Daily Monitor, 20 January. Available: http://www.jamestown.org/programs/edm/single/?tx_ttnews $\% 5$ Btt_news $\% 5 \mathrm{D}=45002 \& \mathrm{cHash}=9418$ ac65669d7525dcf35394ee6a 3 54f\#.V7KMnk196M8 (accessed 23 February 2016).

Verdun, A. and Chira, G.E. 2011. 'The Eastern Partnership: the burial ground of enlargement hopes'. Comparative European Politics, 9(4): 448-66.

Wade, R.H. 2011. 'Emerging world order? From multipolarity to multilateralism in the G20, the World Bank, and the IMF'. Politics \& Society, 39(3): 347-78.

Walker, S.G. 1987. Role Theory and Foreign Policy Analysis. Durham, NC: Duke University Press.

Walt, S.M. 1985. 'Alliance formation and the balance of world power'. International Security, 9(4): 3-43.

Walt, S.M. 2005. Taming American Power. New York: W.W. Norton.

Walt, S.M. 2014. 'The perils of an itchy twitter finger'. Foreign Policy, 21 July. Available: http://www.foreignpolicy.com/articles/2014/07/21/ ukraine_twitter_mh17_shoot_down_russia_us_eu (accessed 1 March 2016).

Waltz, K.N. 1979. Theory of International Politics. New York: Random House.

Waltz, K.N. 2000. 'Structural realism after the Cold War'. International Security, 25(1): 5-41.

Wang, Q.K. and Blyth, M. 2013. 'Constructivism and the study of international political economy in China'. Review of International Political Economy, 20(6): 1276-99.

Wang, Y. 2008. 'Public diplomacy and the rise of Chinese soft power'. Annals of the American Academy of Political and Social Science, 616(1): 257-73. 
Watson, I. and Tkachenko, M. 2010. 'Russia, Ukraine agree on naval-basefor-gas deal'. CNN, 21 April. Available: http://edition.cnn.com/2010/ WORLD/europe/04/21/russia.ukraine/ (accessed 1 March 2016).

Weaver, C. 2011. 'Black Sea regional security: present multipolarity and future possibilities'. European Security, 20(1): 1-19.

Wendt, A.E. 1987. 'The agent-structure problem in international relations theory'. International Organization, 41(3): 335-70.

Wendt, A. 1999. Social Theory of International Politics. Cambridge: Cambridge University Press.

Wenger, A. 2009. 'Russia's energy power'. In J. Perovic, R.W. Orttung and A. Wenger (eds), Russian Energy Power and Foreign Relations: Implications for Conflict and Cooperation. CSS Studies in Security and International Relations. New York: Routledge, pp. 225-54.

White, S., McAllister, I. and Feklyunina, V. 2010. 'Belarus, Ukraine and Russia: East or West?' British Journal of Politics \& International Relations, 12(3): 344-67.

White House, The. 2016. Notice - Continuation of the National Emergency with Respect to Ukraine. Available:https://www.whitehouse.gov/the-pressoffice/2016/03/02/notice-continuation-national-emergency-respect-ukr aine (accessed 1 March 2016).

Whitman, E. 2015. 'Russia suspends Turkish Stream gas pipeline amid tensions over ISIS, downed jet and oil'. International Business Times, 3 December. Available: http://www.ibtimes.com/russiasuspends-turkish-stream-gas-pipeline-amid-tensions-over-isis-downedjet-oil-2209816 (accessed 1 March 2016).

Whitman, R.G. and Juncos, A.E. 2013. 'Stasis in status: relations with the wider Europe'. JCMS: Journal of Common Market Studies, 51(S1): 155-67.

Williams, M.C. 2004. 'Why ideas matter in international relations: Hans Morgenthau, classical realism, and the moral construction of power politics'. International Organization, 58(4): 633-65.

Wohlforth, W.C. 1993. The Elusive Balance: Power and Perceptions During the Cold War. New York: Cornell University Press.

Wohlforth, W.C. 1999. 'The stability of a unipolar world'. International Security, 24(1): 5-41.

Wolfe, J.D. 2011. 'Who rules the EU? Pragmatism and power in European integration theory'. Journal of Political Power, 4(1): 127-44.

Wolfe, R. 1990. 'Atlanticism without the Wall: transatlantic co-operation and the transformation of Europe'. International Journal, 46(1): 137-67.

World Bank. Data. Available: http://data.worldbank.org/ (accessed 1 March 2016).

Worstall, T. 2015. 'Russia and EU play tit for tat with sanctions over 
Ukraine'. Forbes, 22 December. Available: http://www.forbes.com/sites/ timworstall/2015/12/22/russia-and-eu-play-tit-for-tat-with-sanctions-overukraine/\#6e04a4ec6a5d (accessed 1 March 2016).

WTO. 2008. 'WTO welcomes Ukraine as a new member'. Press release. Available: https://www.wto.org/english/news_e/pres08_e/pr511_e.htm (accessed 23 September 2015).

Yelisieiev, K. 2013. 'Ukraine's thorny road to association'. New York Times, 4 April. Available: http://www.nytimes.com/2013/04/05/opinion/global/ ukraines-thorny-road-to-association.html (accessed 23 September 2015).

Youngs, R. 2004. 'Normative dynamics and strategic interests in the EU's external identity'. JCMS: Journal of Common Market Studies, 42(2): 415-35.

Youngs, R. 2009a. "“A door neither closed nor open”: EU policy towards Ukraine during and since the Orange Revolution'. International Politics, 46(4): 358-75.

Youngs, R. 2009b. Energy Security: Europe's New Foreign Policy Challenge. New York: Routledge.

Zakaria, F. 1999. From Wealth to Power: The Unusual Origins of America's World Role. Princeton, NJ: Princeton University Press.

Zakaria, F. 2008. 'Future of American power - how America can survive the rise of the rest'. Foreign Affairs, 87(3): 18-43.

Zalan, E. 2015. 'Nord Stream II: the "elephant" at the EU summit'. EU Observer, 16 December. Available: https://euobserver.com/energy/131551 (accessed 1 March 2016).

Zehfuss, M. 2002. Constructivism in International Relations: The Politics of Reality. Cambridge: Cambridge University Press.

Zielonka, J. 2008. 'Europe as a global actor: empire by example? International Affairs, 84(3): 471-84.

Zielonka, J. 2012. 'The international system in Europe: Westphalian anarchy or medieval chaos?' Journal of European Integration, 35(1): $1-18$.

Zimmerman, W. 2009. The Russian People and Foreign Policy: Russian Elite and Mass Perspectives, 1993-2000. Princeton, NJ: Princeton University Press.

Zimmermann, H. 2007. 'Realist power Europe? The EU in the negotiations about China's and Russia's WTO accession'. JCMS: Journal Of Common Market Studies, 45(4): 813-32.

Zurn, M. and Checkel, J.T. 2005. 'Getting socialized to build bridges: constructivism and rationalism, Europe and the nation-state'. International Organization, 59(4): 1045-79. 


\section{LIST OF INTERVIEWS CONDUCTED}

Interview EU1: Anonymous interview with official from the European Commission's DG Energy in Brussels, 23 September 2013.

Interview EU2: Anonymous interview with official from the European Commission's DG Trade in Brussels, 24 September 2013.

Interview EU3: Anonymous interview with official from the European External Actions Service in Kiev, 27 September 2013.

Interview EU4: Anonymous interview with official from the European External Actions Service in Moscow, 7 October 2013.

Interview RUS1: Anonymous interview with official from the Mission of Russia to the European Union in Brussels, 25 September 2013.

Interview UKR1: Anonymous interview with official from the Mission of Ukraine to the European Union in Brussels, 25 September 2013.

Interview UKR2: Anonymous interview with official from the Ukraine Ministry of Foreign Affairs in Kiev, 3 October 2013. 
Nicholas R. Smith - 9781786430014 Downloaded from PubFactory at 04/26/2023 12:01:33PM via free access 